\title{
Analysis of Japan's Import Demand for Indonesian Plywood by Almost Ideal Demand System Approach
}

\author{
Andreas Rumata Simanjuntak ${ }^{1}$, Suharno ${ }^{2}$, Rita Nurmalina ${ }^{3}$ \\ 1, 2, ${ }^{3}$ Bogor Agricultural University, Department of Agribusiness, Faculty of Economics and Management, \\ Jl. Kamper Wing 4 Level 5 IPB Campus, Babakan, Dramaga, Bogor, Indonesia
}

\begin{abstract}
Plywood is one of the most important commodities of Indonesian forest products. Plywood is included in the top eight products of Indonesian exports with the highest export value. Japan is Indonesia's main export destination. In the last 20 years, Indonesia has become one of the main plywood suppliers for Japan. However, it can be observed from the available data that Malaysia and China become Indonesian rivals. In addition, since 2008 Malaysia had become an exporter with the highest volume for plywood to Japan. This study was conducted to analyze Japan's import policy as well as Indonesia's export policy, along with its competitor countries namely Malaysia and China to obtain information on the decline of Japan's imports for Indonesian plywood. Analysis of the elasticity of demand for plywood in Japan was also performed to determine the elasticity of Indonesian plywood in Japan. The calculation of elasticity of demand was estimated using Almost Ideal Demand System (AIDS) by applying the Seemingly Unrelated Regression (SUR) method. The results of this study show that in general, Indonesia has lower elasticity compared to Malaysia and China from 2007 to 2015. This is indicated by Japan's expenditure elasticity for Indonesian products is lower than the elasticity of Japanese expenditure for Malaysian products. Plywood Indonesia also competes in Japan with Malaysian and Chinese products. This is allegedly due to the policy of increase in demand for Indonesian plywood in Japan issued by the Indonesian government that has not been able to compete with the policies implemented by Malaysia and China. Therefore, the Indonesian government should make more efforts than Malaysia and China to increase the demand for Indonesian plywood in Japan given that Japan's demand for Indonesian plywood is still lower than Malaysia.
\end{abstract}

Keywords: AIDS, Analysis of Import Demand, Indonesia, Plywood.

\section{Introduction}

Plywood is one of the most important commodities of forest products. The high level of worry about environmental degradation has affected the policies to reduce the use of logs as industrial raw materials. This commodity provides an opportunity for the timber industry to keep producing without sacrificing much of the forest to produce a wooden board.

As this plywood commodity is important and strategic, there are a lot of demands from industrialized countries that continue to increase over the years. According to the International Trade Center (ITC), there are two largest plywood importing countries by 2014. Of the 15 million tons of world-traded plywood, 1746469 tons are dominated by United States, and 1665901 tons are imported by Japan from around the world. While in previous years, Japan and America always alternated to become the largest consumer of plywood commodity in the world.

There are three major plywood supplier countries (HS4412) to Japan, i.e. Malaysia, Indonesia and China. Indonesia and Malaysia have always been the main plywood exporter to Japan. For more specific plywood products (HS441231) Malaysia is Indonesia's main rival since 2008 and is a major plywood exporter to Japan defeating Indonesia.

From Intrace 2016 data, it is noted that in 2014 from the total Japan's imports of USD 1,135,406,000 for products having Harmonize System (HS) 441231, Indonesia has a share of USD 493,952,000 and Malaysia is USD 611,771,000. This indicates the presence of two major suppliers on Japan's imports for this type of plywood.

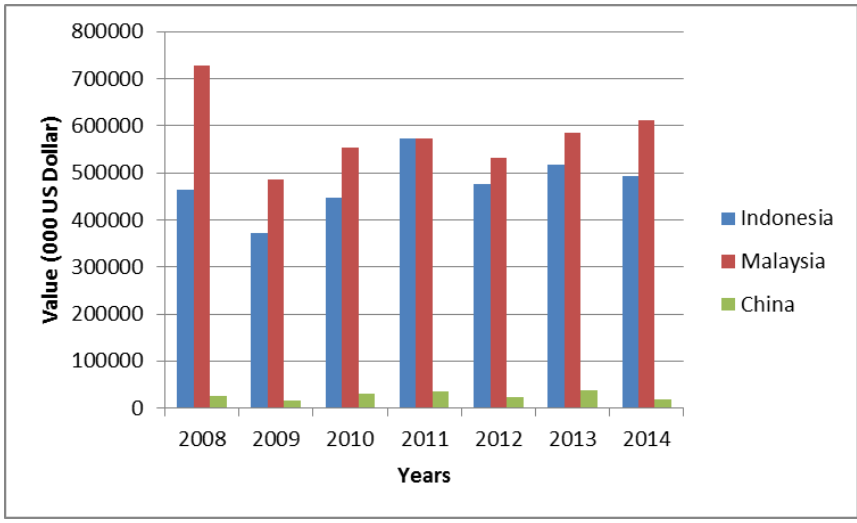

Figure 1: Imported value form three main exporter

Plywood with Harmonize System (HS) 441231 (Plywood; consisting sole of sheets of wood $<=6 \mathrm{~mm}$ thick, at least one outer ply of tropical wood) is the highest level of plywood compared to other types of plywood. This code ranks first from the total and contributes USD 1,135,406,000 (most) from the total plywood imported by Japan. Figure [1] shows the value and total Japan's plywood imports for HS441231 code. Although Indonesian plywood generally dominates the Japanese market, for more specific plywood, Indonesia is under Malaysia. Competition experienced by Indonesia, Malaysia and China for plywood products need to be analyzed to determine the degree of Indonesian plywood competence in the Japanese market. With this research, the information about the competence of plywood Indonesia and 


\section{International Journal of Science and Research (IJSR) \\ ISSN (Online): 2319-7064}

Index Copernicus Value (2015): 78.96 | Impact Factor (2015): 6.391

Japan is obtained, so that Indonesian marketing strategy to win plywood competition in the Japanese market is found. Therefore, this study aims to present policies in Indonesia, Japan and competitor countries that have implications on the plywood trade from Indonesia and other plywood exporting countries. Another objective is to analyze the demand for Japan's Plywood Imports from Indonesia, China and Malaysia with the estimate of the elasticity of AIDS demand.

\section{Theoretical Framework}

Almost Ideal Demand System (AIDS) model was used in this study to answer the objectives through estimation of the parameters in the model. The AIDS model was first introduced by Deaton and Muelbauer (1984) to analyze a consumer demand system. One of its advantages is the ability of first-order approach for demand system. In addition, the AIDS model also accommodates obstacles and is consistent with demand theory such as validity, homogeneity and symmetry (Kahar 2010) that can be tested statistically. Therefore, the AIDS model is commonly used in modeling consumer behavior with a system or simultaneous approach (Deaton 1980).

Along the time, various AIDS models have been developed as in its various models. Some of them are non-linear models (Rahutami 2005), linear AIDS (Puspoari 2012), inverse AIDS (Grant 2005), Dynamics AIDS (Eakins 2003) and Quadratic AIDS (Virgantari 2012).

In addition to the development from its shape, the model also evolves from the aspect of analysis objective. Where the initial introduction of the AIDS model was used to estimate the demand function of eight commodity groups (Deaton and Muelbauer 1980), to address the demand for a commodity in the context of international trade (Riffin 2013 and Chang \& Nguyen).

\section{Research Methods}

Before conducting an analysis with the Model of Almost Ideal Demand System (AIDS), the description of trade policies carried out by importing countries. This descriptive representation was expected to provide guidance later on the estimation result of the elasticity of demand. The results in the form of Japan and Indonesia trade policy data showed why elasticity in Indonesia or the competitors can be low or high. Descriptive analysis in this study was also used to confirm the policy issued by Japan on its relation on the fact that the Japanese wood standard had raised in recent years.

For the AIDS model in this paper, the model was determined based on international trade objectives as had been performed with Seemingly Unrelated Regression (SUR) method (Riffin 2013 and Wan et al 2010):

$$
w_{i}=\alpha_{l}+\sum_{j=1}^{n} \gamma_{\mathrm{ij}} \ln P_{j}+\beta_{i} \ln \left(\frac{x}{p_{*}}\right)
$$

Description:

$w i=$ export share of exporting country $i$

$\mathrm{P}=$ original price of exporting country

$\mathrm{M}=\mathrm{X}=$ total value of world imports
$\mathrm{P}^{*}=$ price index with $\mathrm{P}^{*}=\sum$ wi $\mathrm{Pi}$

The AIDS model that had been built must meet the theoretical barriers of such demand systems

Adding up:

$$
\sum i \text { ai }=1, \sum i Y_{i j}=0, \sum j \beta i=0
$$

Homogenity:

$$
\sum_{i} \quad Y_{i j}=0
$$

and Symetry:

$$
Y_{i j}=Y_{j i}
$$

In addition, elasticity of uncompensated and compensated price as well as the expenditure would be calculated based on the parameters that had been estimated in the model. Elasticity of compensated price (Hicksian) only accommodates substitution effect due to price changes whereas holding "real income" or utility constant. While the elasticity of uncompensated price (Marshallian) accommodates the substitution effect due to price changes, but holding money income constant.

Elasticity of compensated price (eij), uncompensated price (eij) and expenditure ( $\eta$ i) were calculated based on:

$$
\begin{aligned}
& e_{i j}=-\delta_{i j}+\frac{\hat{\gamma}_{i j}}{\bar{w}_{i}}-\hat{\beta}_{i}\left(\frac{\bar{w}_{j}}{\bar{w}_{i}}\right) \\
& e_{i j}^{*}=-\delta_{i j}+\frac{\hat{\gamma}_{i j}}{\bar{w}_{i}}+\bar{w}_{j} \\
& \eta_{i}=1+\frac{\hat{\beta}_{i}}{\bar{w}_{i}}
\end{aligned}
$$

The data used in this study was the monthly data of Indonesia's plywood imports from the first month of 2007 to the last month of 2015. There are three main export countries in the Japanese market determined that is Indonesia, Malaysia and China and this research also used rest of the world (ROW) data.

ROW data was obtained by subtracting the volume or value of Japanese imports from the world by the number of volume or value of Japanese imports from the three countries. The selection of the three countries was based on International Trade Center (Trademap) data showing that these three countries are the main suppliers of Japan's import demand and have a share of more than 90 percent with HS 441231 code. Price variable in this study was determined through price approach (proxy) by dividing the total import value with import volume.

\section{Results and Discussion}

\subsection{Japanese Plywood Import Policy Performance}

There are two main problems of Indonesia's plywood exports: the increasingly stringent policy barriers in Japan given the recent environmental issues and intense competition with other plywood exporters. Tambunan (2006) 


\section{International Journal of Science and Research (IJSR) \\ ISSN (Online): 2319-7064}

Index Copernicus Value (2015): 78.96 | Impact Factor (2015): 6.391

shows that APKINDO (Indonesian Wood Panel Association) reported the decline of export plywood by 50 percent where in 1999 to 2000 it could reach 7 million cubic, in 2005 it only reached 3.5 million cubic. In Japan itself there are regulations that can be considered as tariff barriers and nontariff barriers namely:

\section{a) Tariff Barriers}

Japan's import tariffs for some import commodities are relatively low, at an average of $3.6 \%$. Tariff determination in Japan is based on a Custom Tariff Schedule with HS 9 digits, but for items other than raw materials, Japan adopts an escalation tariff system.

\section{b) Non-Tariff Barriers}

As one means to monitor the quality of goods, the Japanese government imposes a set of regulations that refer to the national interest. For that reason, the goods exported to Japan must follow a set of regulations, among others:

- Plant Protection Law regulates the quarantine system of fruits, vegetables, and plants that are banned in Japan.

- Consumer Product Safety Law regulates procedures for importing and selling consumer goods in Japan.

- Measurement Law regulates the product packaging system with the description about label of content, name and address of importer

- Quarantine Law that regulates quarantine system of imported goods

- Law for Promotion of Sorted and Recycling Containers and Packaging regulates the recycled packaging systems

- Industrial Standardization Law regulates the standard system of industrial product quality

Duty free for import is proposed for several years, but it is rejected by Japan because it is considered to have bad intentions on the interests of raw wood export. Japan is worried that Indonesia cannot suppress massive log smuggling when log export route is opened. In Aneka Bisnis Perdagangan (2012) or various business trading, IJEPA also does not categorize plywood into 211 tariff post of forestry industry products that directly get the duty free for import in Japanese market. Forestry products that have category A are sawn timber, wooden frame, packing box, table and kitchen ware, and other products that are not Indonesia's superior product. According to the Secretary General of the Ministry of Forestry Indonesia, Japan actually places plywood in category C2 and duty free import of $6-10 \%$ is imposed depending on the type and thickness. The provision makes plywood export from Indonesia to Japan unable to maximize the potential for market expansion due to the burden of operational costs.

\subsection{Analysis of Trade Policies of Plywood Exporter Main Rival to Japan}

Malaysia is one of Southeast Asian countries whose trading port activities are very busy. Ray (2003) in Tambunan (2006) mentions that this is due to a more efficient port activity of Malaysia compared to other Southeast Asian ports. For example, although tariffs in Indonesian ports are relatively low, almost all of Indonesia's export plywood is shipped via
Singapore or Malaysia as a result of lack of efficiency in Indonesian ports.

In addition to efficient implementation of the policy in ports, Tachibana (2000) also explained that Malaysia has a world excellent trade policy management practices and forest product management from year to year. This policy includes regulating Selective Harvesting, Minimum Cutting Limits, Post-Felling Inventory, and Directional Felling. They are prescribed to minimize damage to the surrounding environment, which is certainly very much in line with trade policy in Japan.

For China, the high growth of plywood exports to Japan is due to the better climate of China's furniture industry when compare to Indonesia. In Gunawan (2006), the important factors that make Chinese furniture industry better than Indonesia are:

1) Cheaper logs (possibly related to legal wood originating from Indonesia)

2) A more productive workforce

3) Lower bank interest

4) Lower taxes

5) Low overhead costs

6) Convenience of business license process

7) Illegal charges are lower than Indonesia

8) Dumpling politics

It is widely assumed that Indonesian wood industry is able to survive as the industry because it is able to adapt to market conditions better by improving quality control, better design, ability to meet international environmental standards and better marketing in the international market. As it is known, Indonesia's plywood exports in 2008-2012 increased from 1.04 million $\mathrm{m} 3$ in 2008 to 1.22 million $\mathrm{m} 3$ in 2011 . The earthquake and tsunami that destructed Japan in March 2011 damaged many Japanese woods and wood manufactures. In this period, Japan was desperately needed semi-finished goods for housing construction and manufacturing of wood products.

\subsection{Estimation of AIDS Model Equation}

From the results of processing with STATA software, the export share from three plywood exporting countries to Japan is obtained. The result of data analysis is the value of the simultaneous equation with the dependent variable in the form of export share of plywood in Japan and the independent variable is the price of each country (Indonesia, Malaysia, China and ROW). Based on table 2, the R square value for each AIDS model is 11.11 percent for Indonesia, 13.95 percent for Malaysia and 35.7 percent for China. Model of plywood exporter competition in Japan is as equation below: Windo $=0.8009+0.1478$ Ln Pindo -

$$
\begin{aligned}
& 0.1530 \text { Ln PMalay + } 0.0036 \operatorname{Ln} \text { PTiong - } \\
& 0.0015 \text { Ln PROW - } 0.1002 \ln \left(\mathrm{x} /\left(\mathrm{p}^{*}\right)\right)
\end{aligned}
$$

$$
\begin{aligned}
\text { WMalay } & =0.1540-0.1530 \mathrm{Ln} \text { Pindo }+ \\
& 0.1763 \mathrm{Ln} \text { PMalay }-0.0211 \mathrm{Ln} \text { PTiong }- \\
& 0.0021 \mathrm{Ln} \text { PROW }+0.1060 \ln \left(\mathrm{x} /\left(\mathrm{p}^{*}\right)\right)
\end{aligned}
$$




\section{International Journal of Science and Research (IJSR) \\ ISSN (Online): 2319-7064}

Index Copernicus Value (2015): 78.96 Impact Factor (2015): 6.391

Wtiong $=0.0435+0.0036$ Ln Pindo -

0.2110Ln PMalay + 0.1501 Ln PTiong +

0.0024 Ln PROW - $0.0070 \ln \left(\mathrm{x} /\left(\mathrm{p}^{*}\right)\right)$

Each of the equations above showed the equation of Indonesia export share (Windo), Malaysian export share (Wmalay) and China export share (Wtiong).

\subsection{Competition of Plywood Exporting Countries in Japanese Market}

The plywood exporter competition in Japan can be analyzed through the approach of calculation of the value of elasticity of expenditure, compensated elasticity, and uncompensated elasticity. Each calculation is obtained from the estimated parameters in the AIDS model.

\subsubsection{Elasticity of Expenditure}

Table [1] shows that the major plywood import source countries to Japan have an average share of 99.5 percent of imports while the other countries are showed by the share value of rest of the world (ROW) by only 0.5 percent. Malaysia is an import source with the largest share of imports to meet the demand for Japan's plywood imports by 53.1 percent. In addition, from table [1] there is a sign of the elasticity of expenditure from each country of positive import source.

This indicates that plywood originating from the three importing countries of plywood is normal goods. Indonesia has an expenditure elasticity value of 0.77 percent. It means that if there is an additional 1 percent import of Japanese plywood, then the import expenditure will increase the demand for plywood import from Indonesia by 0.77 percent. The value of elasticity of Indonesia's expenditure also reflects the elasticity of the inelastic expenditure because its absolute value is less than one percent. Malaysia has an elastic expenditure elasticity value that is better by 1 percent, or 1.19 percent. It means that that an increase in Japanese plywood imports from Malaysia by 1 percent will increase the demand for plywood imports from Malaysia by 1.19 percent.

Table 1: Share of Import and Elasticity of Import Source Country Expenditure 2007-2015 (monthly data)

\begin{tabular}{|l|l|l|}
\hline Import Source Country & Average Share & Elasticity of Expenditure \\
\hline
\end{tabular}

\begin{tabular}{|c|c|c|}
\hline Indonesia & 0.44209 & 0.77330 \\
\hline Malaysia & 0.53139 & 1.19951 \\
\hline China & 0.02175 & 0.67450 \\
\hline Total & 0.99525 & \\
\hline Rest of World & 0.00474 & 1.269998 \\
\hline
\end{tabular}

\subsubsection{Compensated Elasticity}

Compensated elasticity is the elasticity of demand, unaffected by world expenditure or imports. Compensated Elasticity or Hicksian elasticity calculates the own price elasticity or cross price. The result of elasticity of demand on Hicksian elasticity can be seen in Table [2]
Table 2: Elasticity of Demand of Hicksian Model for Indonesia, Malaysia, China and ROW

\begin{tabular}{|l|l|l|l|l|}
\hline Compensated & Indonesia & Malaysia & China & ROW \\
\hline Indonesia & -0.223 & 0.1851 & 0.0299 & 0.0082 \\
\hline Malaysia & 0.2433 & -0.1368 & -0.0179 & 0.0007 \\
\hline China & 0.1889 & -0.4385 & -0.2883 & 0.1176 \\
\hline
\end{tabular}

\section{a) Own Price Elasticity}

The elasticity indicator of each country shows that the price elasticity of the three countries is negative. Indonesia -0.223 , it means that if the price of Indonesian plywood increases by 1 percent then the share of plywood imports coming from Indonesia will decrease by 0.223 percent.

\section{b) Cross elasticity}

There are two indicators of cross-elasticity that is positive and negative. If elasticity is negative, it indicates a complementary relationship, whereas a positive sign indicates a substitutive relationship between each of these countries. The cross elasticity value between Malaysia and China is -0.179 percent. It means that if the price of plywood imports from China increases, then, the share of plywood imports from Malaysia decreases by 0.0179 percent. The relationship between Malaysia and China is complementary, meaning that the two commodities originating from the two countries are different and complementary (Medelin 2001). Medelin statement shows that plywood from Malaysia and China does not compete with each other in Japan. This is also reinforced by the cross elasticity value between China and Malaysia with a negative value of -0.179 .

The mutual substitution relationship is shown by the positive cross elasticity value between Indonesia - Malaysia and Indonesia - China and vice versa. For example, the relationship between Indonesia and Malaysia has a cross elasticity value of 0.185 percent. It means that if the price of plywood imports from Malaysia increases by 1 percent then the share of plywood imports from Indonesia will also increase by 0.185 percent.

\subsubsection{Uncompensated Elasticity}

The uncompensated elasticity shows elasticity affected by world expenditure or imports. Uncompensated elasticity or Marshallian Elasticity calculates the own price elasticity or cross price. The result of elasticity of Marshallian Elasticity demand can be seen in Table [3].

Table 3: Elasticity of Demand of Marshallian Model for Indonesia, Malaysia, China and ROW

\begin{tabular}{|c|c|c|c|c|}
\hline Uncompensated & Indonesia & Malaysia & Tiongkok & ROW \\
\hline Indonesia & -0.5652 & -0.225 & 0.013 & 0.004 \\
\hline Malaysia & -0.376 & -0.7742 & -0.044 & -0.004 \\
\hline Tiongkok & 0.3110 & -0.796 & -0.303 & 0.114 \\
\hline
\end{tabular}

\section{a) Own Price Elasticity}

Similar to the Hicksian model on price elasticity, the indicators of elasticity of each country show the value of its own price elasticity that is negative. This indicates that the increase in plywood price of import source country by 1 percent will decrease the share of the country imports. Indonesia is -0.565 percent, Malaysia -0.774 percent, and 


\section{International Journal of Science and Research (IJSR) \\ ISSN (Online): 2319-7064}

Index Copernicus Value (2015): 78.96 | Impact Factor (2015): 6.391

China -0.303 percent. These figures show that the most elastic country is Malaysia while the one with the lowest elasticity is China.

\section{b) Cross elasticity}

Unlike Compensated Elasticity, on the Uncompensated Elasticity model in addition to Malaysia and China, a complementary relationship exists between Indonesia and Malaysia. The value of Indonesia's cross elasticity with Malaysia is -0.225 percent. It indicates that if Malaysia's import price increases by 1 percent then the share of Indonesian imports decreases by 0.225 percent. This figure shows the mutually complementary relationship between Indonesia and Malaysia where each country commodity does not compete with each other.

The plywood competition is found only in the relationship between Indonesia and China / China and Indonesia. The value of Indonesia's elasticity with China is 0.013 percent. It means that if the price of plywood imports from China increases by 1 percent then the share of Indonesian imports will increase by 0.013 percent.

\section{Conclusion and Suggestion}

\subsection{Conclusion}

The policy regarding the increase in demand for Indonesian plywood in Japan issued by the government has not been able to compete with the policies adopted by Malaysia and China. Based on the results of demand analysis using the AIDS model calculation, it shows that in general, Indonesia is has lower elasticity compared to Malaysia and China from 2007 to 2015. This is indicated by Japan's expenditure elasticity for Indonesian products that is lower than the elasticity of Japan's expenditure for Malaysian products. Indonesian plywood also competes with Malaysian and Chinese products in Japan.

\subsection{Suggestion}

The government should make more efforts than Malaysia and China to increase the demand for Indonesian plywood in Japan as Japan's demand for Indonesian plywood is still lower compare to Malaysia. For further research, it is necessary to add additional elements to increase the competitiveness of Indonesian plywood as well as any factors that may increase the demand for Indonesian plywood in Japan.

\section{References}

[1] Bugin, Burhan. 2003. Analisis Data Penelitian Kualitatif. Jakarta : PT. Raja Grafindo Persada.

[2] Deaton A, Muellbauer J. 1980. An Almost Ideal Demand System. TheAmerican Economic Review. 70(3): 312-326

[3] Eakins JM, Gallagher LA. 2003. Dynamic Almost Ideal Demand System: An Empirical Analysis of Alcohol Expenditure in Ireland. Applied Economics. 35(9):1025-1036.
[4] Gujarati, N., Damodar dan Porter, C., Dawn. 2009. Basic Econometrics, Fifth Edition McGraw-Hill International Edition

[5] Medelin J. 2001. Caribbean Demand of US and Rest of the World Starchy Food (Wheat, Rice, Corn and Fresh Potatoes): A Restricted Source Differentiated Almost Ideal Demand System. Lecturas de Economia. No 55

[6] Ohashi 2009. Timber Imports and Market Situation in Japan. Yokohama: Japan Lumber Importer's Association (JLIA).

[7] Setiawan 2013. Policy Analysis of Demand for Indonesian Plywood [thesis]. Yogyakarta : Universitas Gadjah Mada.

[8] Tachibana 2000. Forest-Related Industries and Timber Exports of Malaysia (Policy and Structure). Tokyo: University of Tokyo Yayoi

[9] Tambunan 2006. The Growth and Competitiveness of Indonesia's Wood Furniture Export. Jakarta: Kadin Indonesia-Jetro.

[10] Todaro, M.P, S.C. Smith. 2003. Pembangunan Ekonomi Di Dunia Ketiga. Edisi Kedelapan. Jakarta: Erlangga.

\section{Author Profile}

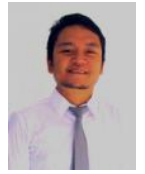

Andreas Rumata Simanjuntak received the bachelor degrees in Bogor Agricultural University, Department of Agribusiness, Faculty of Economics and Management,in 2012, respectively. He now study in Graduate School of Bogor Agricultural University Department of Agribusiness, Faculty of Economics and Management.

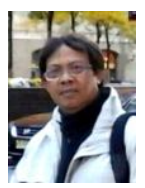

Suharno, Dr. Ir. MA.Dev received the bachelor degrees in Bogor Agricultural University, Faculty of Agricultural, respectively. He get the master degree in State University of Ghent - Belgia. He received doctoral degree in Georg August University Goettingen - Germany. He now lecture in Graduate School of Bogor Agricultural University Department of Agribusiness, Faculty of Economics and Management .

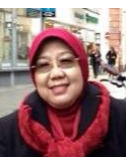

Rita Nurmalina, Prof. Dr. Ir. MS received the bachelor degrees in Bogor Agricultural University, Faculty of Agricultural, respectively. She received the master and doctoral degree in Graduate School of Bogor Agricultural University. Now sheow lecture in Graduate School of Bogor Agricultural University Department of Agribusiness, Faculty of Economics and Management . 